\title{
The 2 Ga eclogites of central Tanzania: directly linking age and metamorphism
}

\author{
R. TAMBLYN ${ }^{1}$, D. BROWN ${ }^{1}$, M. HAND ${ }^{1}$, L. MORRISSEY ${ }^{2}$, \\ R. ANCZKIEWICZ ${ }^{3}$ \\ ${ }^{1}$ Department of Earth Sciences, The University of Adelaide, \\ Adelaide, Australia \\ ${ }^{2}$ School of Natural and Built Environments, The University \\ of South Australia, Adelaide, Australia \\ ${ }^{3}$ Polish Academy of Sciences, Kraków, Poland
}

The ca. 2 Ga eclogites in the Usagaran Belt in central Tanzania are amoung the oldest documented eclogites in the world. As such, they have been used to pinpoint the thermal conditions of the onset of modern-style subduction on Earth. Two samples of mafic eclogite, one coarse-grained and partially retrogressed, and one fine-grained and extensively retrogressed, have been interrogated to reconstruct the metamorphic history of the ca. 2 Ga subducted crust. The samples are $1 \mathrm{~km}$ apart, separated by a mylonitic upper amphibolite-transitional granulite foliation. Mineral equilibria modelling suggests the eclogites reached at least $\sim 18 \mathrm{kbar}$ and $\sim 700{ }^{\circ} \mathrm{C}$, consistent with a warm subduction geothermal gradient. These conditions were then followed by transitional amphibolite-granulite facies overprinting. However, geochronology and mineral zoning patterns suggest the two eclogites experienced different thermal-time histories. Lu-Hf garnet geochronology from the partially retrogressed eclogite pinpoints eclogite facies metamorphism to ca. $1994 \mathrm{Ma}$. U-Pb zircon geochronology in the extensively retrogressed eclogite points to a longer burial history, with possibly $\sim 100 \mathrm{Ma}$ of zircon growth in the presence of garnet. Major, trace element and REE garnet zoning profiles from the extensively retrogressed are flat, consistent with a extended duration at high temperatures. In contrast the partially retrogressed eclogite shows well preserved major, trace and REE zonation patterns from similar sized garnet grains, suggesting a much shorter exposure to high temperatures. Geochronology coupled with garnet compositional data suggests the possible accumulation of rocks with different temporal evolutions within the same subduction system. This data, combined with data from eclogites from the Eburnian-Transamazonian and Ubende orogens, demonstrate the possible existence of a large subduction system on the margin of west Africa from ca. 2.1$1.9 \mathrm{Ga}$. This system has led to the preservation of several eclogitic rocks, which suggests that modern-style subduction was operating on significant geographic and temporal scales at this time. 